\title{
Unusual Occurrence of Intestinal Pseudo Obstruction in a Patient with Maternally Inherited Diabetes and Deafness (MIDD) and Favorable Outcome with Coenzyme Q10
}

\begin{abstract}
Maternally inherited diabetes and deafness (MIDD) has been related to an $A$ to $\mathrm{G}$ transition in the mitochondrial tRNA Leu (UUR) gene at the base pair 3243. This subtype of diabetes is characterized by maternal transmission, young age at onset and bilateral hearing impairment. Besides diabetes and deafness, the main diagnostic features, a wide range of multisystemic symptoms may be associated with the A3243G mutation. Organs that are most metabolically active, such as muscles, myocardium, retina, cochlea, kidney and brain are frequently affected. Gastrointestinal tract symptoms are also common in patients with mitochondrial disease and constipation and diarrhea are the most frequent manifestations. However, there are few prior reports of intestinal pseudo obstruction in MIDD patients. Here we report the case of a patient with MIDD associated with the mtDNA A3243G mutation who developed chronic intestinal pseudo obstruction, and the introduction of Coenzyme $\mathrm{Q} 10$ as adjunctive therapy led to a solution of the pseudo obstruction. (Arq Bras Endocrinol Metab 2008; 52/8:1345-1349)
\end{abstract}

Keywords: Pseudo intestinal obstruction; MIDD; Coenzyme Q10

\section{RESUMO}

Pseudo-Obstrução Intestinal em Paciente com Diabetes Mitocondrial que Apresentou Boa Resposta ao Tratamento Adjunto com Coenzima Q10.

Diabetes mitocondrial ou diabetes e surdez de herança maternal (MIDD, acrônimo de maternally inherited diabetes and deafness) é freqüentemente associado à mutação mitocondrial A3243G. Esse subtipo de diabetes é caracterizado por transmissão materna, disacusia neuro-sensorial bilateral e idade precoce de aparecimento. Além do diabetes e da surdez, principais características diagnósticas, outros sintomas em diferentes órgãos podem também associar-se à mutação A3243G. Os órgãos que são metabolicamente mais ativos, tais como músculos, miocárdio, retina, cóclea, rim e cérebro, são freqüentemente afetados. Sintomas do trato gastrintestinal também são comuns em pacientes com doença mitocondrial, sendo diarréia e obstipação as manifestações mais freqüentes. Entretanto, há poucos relatos de pseudo-obstrução intestinal em portadores de diabetes mitocondrial. Este relato descreve o caso de uma paciente com diabetes mitocondrial que apresentou pseudo-obstrução intestinal e que com a introdução de coenzima Q10, como terapia adjunta, teve resolução o quadro. (Arq Bras Endocrinol Metab 2008; 52/8:1345-1349)

Descritores: Diabetes mitocondrial; MIDD; Coenzima Q10; Pseudo-obstrução intestinal

\section{INTRODUCTION}

aternally-inherited diabetes and deafness (MIDD) or mitochondrial diabetes mellitus (OMIM 520000), in the large majority of the cases, clinical case report

\author{
Carla S. Bergamin \\ Luiz Clemente Rolim \\ SERGIO A. DIB \\ Regina S. MoIsÉS
}

Disciplina de Endocrinologia, Escola Paulista de Medicina, Universidade Federal de São Paulo, São Paulo, SP, Brasil.

Paulo, Sà Paulo, SPBasi. 
has been related to an A to $\mathrm{G}$ transition in the mitochondrial tRNA Leu (UUR) gene at the base pair 3243 (1-4). This subtype of diabetes is characterized by maternal transmission, as the name suggests, young age at onset and bilateral hearing impairment (5). Some patients become rapidly dependent on insulin treatment and might be diagnosed as type 1 diabetes, while others, can be managed with a diet or oral hypoglycemic agents for a variable time period and are often classified as type 2 diabetes. However, insulinopenia is progressive and some years after the onset of diabetes, most patients will need insulin therapy.

The underlying defect in mitochondrial diabetes is a progressive impairment of insulin secretion (6-8). The molecular mechanism by which the A3243G mutation affects insulin secretion may involve ATP generation, since high plasma glucose concentration, via glycolysis and mitochondrial metabolism, leads to high ATP/ADP ratios within the cell. This ratio is sensed by subunits of ATP-sensitive potassium channels, closing them, which results in membrane depolarization. This process triggers the opening of voltage-gated calcium channels, causing calcium influx and insulin release. Thus, any change in the biochemical pathway linking glucose uptake and ATP generation can possibly impair the efficiency by which glucose stimulates insulin secretion. Furthermore, mitochondrial diabetes does show a pronounced age - dependent deterioration of pancreatic function indicating involvement of additional processes.

The prevalence of MIDD in diabetic population accounts for $0.2-3 \%$, depending on the ethnic background (9-11). In samples of our population previous studies showed a frequency of $0.4 \%(12,13)$.

Besides diabetes and deafness, the main diagnostic features, a wide range of multisystemic symptoms may be associated with the A3243G mutation. Organs that are most metabolically active, such as muscles, myocardium, retina, cochlea, kidney and brain are frequently affected. Gastrointestinal tract symptoms are also frequent in patients with mitochondrial disease. Gastrointestinal dysmotility, including diarrhea and pseudo-obstruction, is the most prominent manifestation of MNGIE (Mitochondrial NeuroGastroIntestinal Encephalomyopathy), an autosomal gene defect that induces multiple mtDNA deletions (14). In another mitochondrial disease, MELAS (myopathy, encephalopathy, lactic acidosis and stroke-like episodes), ischaemic colitis, chronic diarrhea and intestinal obstruction have been described before (15-18). In MIDD, Narbonne et al found constipation, diarrhea, or both in $88 \%$ of patients bearing the A3243G mutation (19).

In clinical practice, constipation in a diabetic patient is treated conservatively with the usual methods using bulk agents and stool softeners. If these agents fail, laxatives used prudently can be quite helpful. Cisapride was shown to have prokinetic properties in some, but not all patients with idiopathic or diabetic constipation. Not frequently, colonic dysfunction in diabetic patients may lead to more severe colonic disorders as a marked sigmoid dilatation.

Coenzyme Q10 (CoQ10) plays a central role in the mitochondrial respiratory chain by acting as an electron carrier. In addition, Co Q10 has also antioxidant and membrane stabilizing properties. There are previous reports showing beneficial effects of CoQ10 on some neuromuscular symptoms, prevention of progressive insulin secretory defect, exercise intolerance, hearing loss and myocardial dysfunction in MIDD patients (20-23).

Here we report the unusual occurrence of intestinal pseudo obstruction in a patient with a MIDD and the therapeutic usefulness of Coenzyme Q10.

\section{SUBJECTS AND METHODS}

A 47-year-old woman with sensorial hearing loss and diabetes presented with abdominal distension and constipation.

\section{Molecular analysis of A3243G mutation}

Total DNA was extracted from peripheral blood leukocytes using a commercial kit (Puregene DNA Isolation Kit, Gentra System, Minneapolis, MN, USA). Detection of the 3243 A-to-G transition in the mitochondrial tRNA Leu (UUR) gene was carried out by polymerase chain reaction A3243G (PCR), Apa I digestion, and acrylamide gel electrophoresis. Bands were visualized by ethidium bromide staining.

\section{RESULTS}

\section{Case Report}

A 47-year-old diabetic woman presented with recurrent pain and abdominal distention and severe constipation, who had already prompted previous hospitalizations. 
Surgical treatment had already been proposed due to non-response to usual clinical management.

She was diagnosed with diabetes mellitus at the age of 11 years and had been treated with insulin since then. Progressive bilateral sensorineural hearing loss developed at age 27 and required cochlear implant. She also developed proliferative diabetic retinopathy requiring laser photocoagulation and end-stage renal failure, being on hemodialysis treatment for one year.

She had a family history of diabetes mellitus and hearing loss in her mother, two sisters and a nephew. Her mother had a history of abdominal distension and died due to clinical complications related to an intestinal rupture.

Molecular genetic analysis was conducted in the patient and available relatives. The presence of the heteroplasmic point mutation at position 3243 (A3243G) of mtDNA was found in the patient, her sister and nephew, which confirmed the diagnosis of MIDD. We were told that the proband's daughter had hearing impairment and glucose intolerance but we could not examine her (Figure 1).

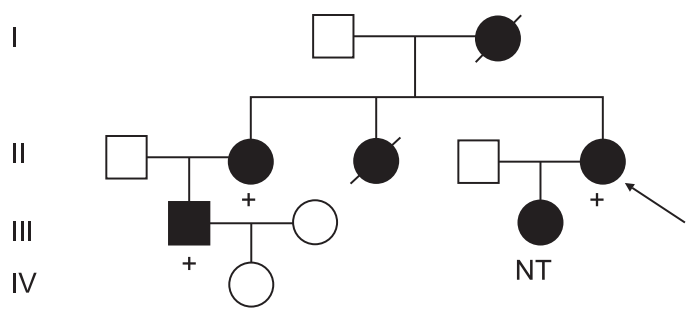

Figure 1. Pedigree of the studied family. The individuals with diabetes mellitus and hearing impairment are represented with filled symbols. Arrow indicates the proband. + denotes presence of $\mathrm{A} 3243 \mathrm{G}$ mutation. NT = not tested.

The patient BMI was $22.1 \mathrm{~kg} / \mathrm{m} 2$ and her $\mathrm{HbAlc}$ level was $10.0 \%$ (normal range: 4.0-6.1\%). Sensory and motor polyneuropathy were detected by neurological examination and electromyography. Intestinal and colon transit time showed diffuse bowel dilatation, megaduodenum and colonic inertia. CT scan showed diffuse stomach and intestinal dilatation without stenosis ( $\mathrm{Fi}-$ gure 2). Based on these findings, the diagnosis of intestinal pseudo occlusion was made. Despite of treatment with prokinet and antiemetics agents, the symptoms persisted. After this, Co Q10 $100 \mathrm{mg} /$ day was added to the treatment. She responded well and her symptoms improved. Thereafter, after a three year followup, she experienced no gastrointestinal symptoms.

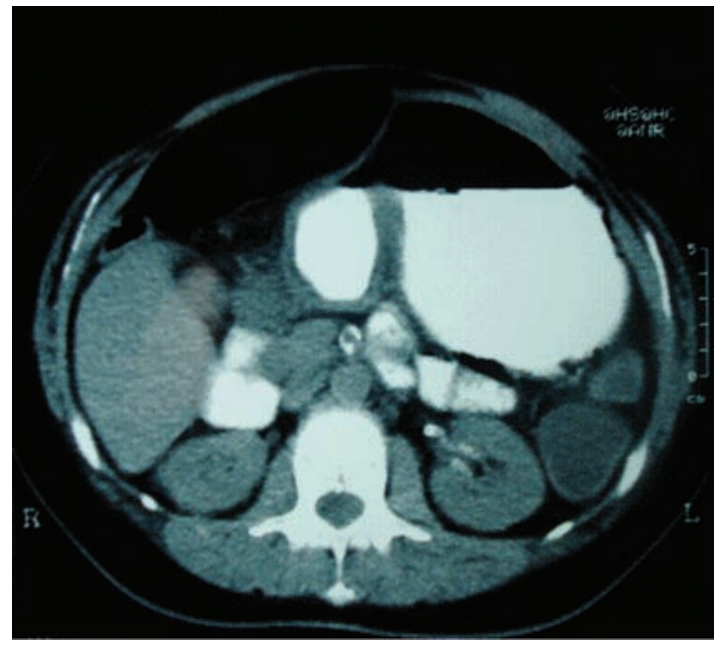

Figure 2. Abdominal CT scan shows distended bowel loops with air-fluid levels, without stenosis, suggesting intestinal pseudo-obstruction.

\section{DISCUSSION}

Here we report the case of a patient with MIDD associated with the mtDNA A3243G mutation who developed chronic intestinal pseudo obstruction and responded well to the treatment with Coenzyme Q10.

MIDD, although a rare condition, is important to be correctly diagnosed since it has implications on therapeutics, screening of associated manifestations and family screening. It appears to be a decreased prevalence of diabetic retinopathy in MIDD. Guillausseau el al found that despite a mean duration of diabetes of 12 years, only $8 \%$ of patients exhibited diabetic retinopathy (24). Similar findings were obtained by Holmes-Walker and cols. (25). In contrast, the prevalence of nephropathy is high. Massin et al in a French multicenter study found renal dysfunction in $53.7 \%$ of MIDD patients compared with $28.5 \%$ in diabetic controls without A3243G mutation (26). The most prevalent finding in kidney biopsies is focal segmental glomerulosclerosis $(24,27)$. These findings suggested that a specific mitochondrial defect, rather than diabetic nephropathy, may be responsible for renal impairment in MIDD. Our patient, during the evolution of MIDD, developed endstage renal disease. Since she had longstanding diabetes, poor metabolic control and severe diabetic retinopathy, we can infer that the primary cause of her renal disease was a diabetic nephropathy. However, specific mitochondrial kidney disease cannot be excluded. 
Gastrointestinal tract symptoms are frequent in MIDD patients. Narbonne et al found that constipation was the most frequent manifestation, but diarrhea, nausea or vomiting and abdominal pain were also found (19). However, there are few prior reports of intestinal pseudo obstruction in MIDD patients (19,28). Pseudo intestinal obstruction is a severe condition characterized by disabling and potentially life-threatening complications over time (29). Accordingly, Narbonne et al reported the case of a fatal intestinal pseudo obstruction in a patient with severe MIDD (19) and Hiel et al in a patient with MELAS (30). The etiology of this condition in mitochondrial diseases is unclear. The abnormality can be due to either a miogenic or neurogenic origin, or both $(14,28,31,32)$. In the present pedigree, the proband carrying the mtDNA A3243G mutation developed intestinal pseudo obstruction and her mother, an obligatory carrier of the mutation, had symptoms that resemble the same condition and resulted in her death, illustrating the familial occurrence of intestinal pseudo obstruction.

Coenzyme Q10 acts as an electron carrier of the respiratory chain in mitochondria and has also antioxidant and membrane stabilizing properties. Shimotake and cols. (17) reported the use of intravenous administration of Co Q10 in MELAS children who developed intestinal pseudo obstruction, resulting in gradual recovery in the following days. However, there are also reports of the occurrence of intestinal pseudo obstruction in patients already using Co Q10 $(18,19,33)$. In our patient the introduction of Co Q10 as adjunctive therapy led to a resolution of the pseudo obstruction.

In summary, here we report the case of diabetic patient diagnosed as MIDD associated to mitochondrial DNA A3243G mutation who developed chronic intestinal obstruction and responded well to the treatment with Coenzyme Q10. Intestinal pseudo obstruction is a rare but severe condition and Coenzyme Q10 may be an adjunctive therapy for this condition in MIDD patients.

No potencial conflict of interest relevant to this article was reported.

\section{REFERENCES}

1. Van den Ouweland JMH, Lemkes HHPJ, Ruitenbeek W, Sandkuijl LA, de Vijlder MF, Struyvenberg PA, et al. Mutation in the mitochondrial tRNALEU(UUR) gene in a large pedigree with maternally transmitted type II diabetes and deafness. Nat Genet. 1992;1(5):368-71.

2. Reardon W, Ross RJ, Sweeney MG, Luxon LM, Pembrey ME, Harding AE, Trembath RC. Diabetes mellitus associated with a pathogenic point mutation in mitochondrial DNA. Lancet. 1993;340(8832):1376-9.

3. Kadowaki T, Kadowaki $H$, Mori $Y$, Tobe K, Sakuta $R$ et al. A subtype of diabetes mellitus associated with a mutation of mitochondrial DNA. N Engl J Med. 1994;330(14):962-8.

4. Di Mauro S, Schon, EA. Mechanisms of Disease: Mitochondrial Respiratory-Chain Diseases. N Engl J Med. 2003;348(26): 2656-68.

5. Maassen JA, 't Hart LM, van Essen E, Heine RJ, Nijpels G, Tafrechi RSJ, et al. Mitochondrial Diabetes. Molecular Mechanis$\mathrm{ms}$ and Clinical Presentation. Diabetes, 2004;53 Suppl 1: S103-S109.

6. Oka $Y$, Katagiri $H$, Ishihara $H$, Asano $T$, Kobayashi T, Kikuchi M. Beta-cell loss and glucose induced signaling defects in diabetes mellitus caused by mitochondrial tRNALeu (UUR) gene mutation. Diabet Med. 1996;9 Suppl 6:S98-S102.

7. Velho G, Byrne MM, Clément C, Sturis J, Pueyo ME, Blanché H et al. Clinical phenotypes, insulin secretion, and insulin sensitivity in kindreds with maternally inherited diabetes and deafness due to mitochondrial tRNALeu (UUR) gene mutation. Diabetes. 1996;45(4):478-87.

8. Salles JE, Kasamatsu TS, Dib SA, Moisés RS. B-cell function in individuals carrying the mitochondrial tRNA Leu (UUR) mutation. Pancreas. 2007;34(1):133-7.

9. Saker PJ, Hattersley AT, Barrow B, Hammersley MS, Horton V, Gillmer MD, Turner RC. UKPDS 21: low prevalence of the mitochondrial transfer RNA gene (tRNA(Leu(UUR))) mutation at position 3243bp in UK Caucasian type 2 diabetic patients. Diabet Med.1997;14(1):42-5.

10. Katagiri $H$, Asano $T$, Ishihara $H$, Inukai $K$, Anai $M$, Yamanouchi $\mathrm{T}$, et al. Mitochondrial diabetes mellitus: prevalence and clinical characterization of diabetes due to mitochondrial tRNA (Leu(UUR)) gene mutation in Japanese patients. Diabetologia. 1994;37(5):504-10.

11. Ohkubo K, Yamano A, Nagashima M, Mori Y, Anzai K, Akehi Y, et al. Mitochondrial gene mutations in the tRNA(Leu(UUR)) region and diabetes: prevalence and clinical phenotypes in Japan. Clin Chem. 2001;47(9):1641-8.

12. Salles JE, Kalinin LB, Ferreira SRG, Kasamatsu T, Moisés RS. Diabetes mellitus associado à mutação mitocondrial A3243G: freqüência e caracterização clínica. Arq Bras Endocrinol Metab. 2007;51(4):559-65.

13. Crispim D, Tschiedel B, Souto KEP, Roisenberg I. Prevalence of three mitochondrial DNA mutations in type 2 diabetic patients from southern Brazil. Clin Endocrinol. 2002;57(1):141-2.

14. Hirano M, Silvestri G, Blake DM, Lombes A, Minetti C, Bonilla $E$, et al. Mitochondrial neurogastrointestinal encephalomyopathy (MNGIE): clinical, biochemical, and genetic features of an autosomal recessive disorder. Neurology. 1994;44(4): 721-7.

15. Hess J, Burckhard P, Morris M, Laliot M, Myers P, Hadenque A. Ischaemic colitis due to mitochondrial cytopathy. Lancet. 1995;346(8968):189-90

16. Kishimoto $M$, Hashiramoto $M$, Kanda F, Tanaka M, Kasuga M. Mitochondrial mutation in diabetic patient with gastrointestinal symptoms. Lancet. 1995;345(8947):142.

17. Shimotake T, Furukawa T, Katsuhiro I, Iwai N, Takeuchi Y. Familial occurrence of intestinal obstruction in children with the syndrome of mitochondrial encephalomyopathy, lactic acido- 
sis and stoke-like episodes (MELAS). J Pediatr Surg. 1998;33 (12):1837-9.

18. García-Velasco A, Gómez-Escalonilla C, Guerra-Vales JM, Cabello A, Campos Y, Arenas J. Intestinal pseudo-obstruction and urinary retention: cardinal features of a mitochondrial DNA-related disease. J Intern Med. 2003;253(3):381-5.

19. Narbonne H, Paquis-Fluckinger V, Valero R, Heyries L, Pellissier JF, Vialettes B. Gastrointestinal tract symptoms in Matternally Inherited Diabetes and Deafness (MIDD). Diabetes Metab. 2004;30(1):61-6.

20. Suzuki Y, Kadowaki H, Atsumi Y, Hosokawa K, Katagiri H, Kadowaki T, et al. A case of diabetic amyotrophy associated with 3243 mitochondrial tRNA(leu; UUR) mutation and successful therapy with Coenzyme Q10.Endocrine J. 1995;42(2):141-5.

21. Suzuki $S$, Hinokio $Y$, Ohtomo $M$, Hirai $M$, Hirai $A$, Chiba $M$, et al. The effects of coenzyme $\mathbf{Q} 10$ treatment on maternally inherited diabetes mellitus and deafness, and mitochondrial DNA 3243 (A to G) mutation. Diabetologia. 1998;41(5):584-8.

22. Suzuki $Y$, Taniyama M, Muramatsu $T$, Atsumi $Y$, Hosokawa $K$, Asahina $T$, et al. Diabetes mellitus associated with mitochondrial tRNA Leu (UUR) mutation: clinical features and Coenzyme Q10 treatment. Mol. Aspects Med. 1997;18 Suppl 1:S181-8.

23. Salles JE, Moisés VA, Almeida DR, Chacra AR, Moisés RS. Myocardial dysfunction in mitochondrial diabetes treated with Coenzyme Q10. Diabetes Res Clin Pract. 2006;72(1):100-.

24. Guillausseau PJ, Massin P, Dubois-LaForgue D, Timsit J, Virally $M$, Gin $H$, et al. Maternally inherited diabetes and deafness: a multicenter study. Ann Intern Med. 2001;134(9):721-8.

25. Holmes-Walker DJ, Mitchell P, Boyages SC. Does mitochondrial genome mutation in subjects with maternally inherited diabetes and deafness decrease severity of diabetic retinopathy? Diabet Med. 1998;15(11):946-52.

26. Massin P, Dubois-Laforgue D, Meas T, Laloi-Michelin M, Gin H, Bauduceau B, et al. Retinal and renal complications in patients with a mutation of mitochondrial DNA at position 3,243 (maternally inherited diabetes and deafness). A case-control study. Diabetologia. 2008;51(9):1664-70.
27. Nakamura S, Yoshinari M, Doi Y, Yoshizumi H, Katafuchi R, Yokomizo $Y$, et al. Renal complications in patients with diabetes mellitus associated with an $A$ to $G$ mutation of mitochondrial DNA at the position 3243 of leucine tRNA. Diabetes Res Clin Pract. 1999;44(3):183-9.

28. Aoki Y, Hosaka S, Kiyosawa K. Intestinal Pseudo-Obstruction in a Diabetic Man: Role of the Mitochondrial A3243G Mutation. Ann Intern Med. 2002;137(8):703-4.

29. Antonucci A, Fronzoni L, Cogliandro L, Cogliandro R, Stanghellini V, et al. Chronic intestinal pseudo-obstruction. World J Gastroenterol. 2008;14(19):2953-61.

30. Hiel JAP, Verrips A, Keyser A, Jansen TLTA, Wesseling P, Coo R, Gabreëls FJM. Ileus in mitochondrial encephalomyopathy, lactic acidosis and stroke-like episodes. Neth J Med. 1998;53 (1):27-31.

31. Campos Y, Martin MA, Caballero C, Rubio JC, de la Cruz F, Tuñón $T$, et al. Single large-scale mitochondrial DNA deletion in a patient with encephalopathy, cardiomyopathy, and prominent intestinal pseudoobstruction. Neuromuscul Disord. 2000;10(1):56-8.

32. Chimmery PF, Jones S, Sviland L, Andrews RM, Parsons TJ, Turnbull DM, et al. Mitochondrial enteropathy: the primary pathology may not be within the gastrointestinal tract. Gut. 2001;48 (1):121-4.

33. Yamamoto M, Sato T, Anno M, Ujike H, Takemoto M. Mitochondrial myopathy, encephalopathy, lactic acidosis, and strokelike episodes with recurrent abdominal symptoms and coenzyme Q10 administration. J Neurol Neurosurg Psychiatry. 1987;50(11):1475-81.

\section{Correspondence to:}

Regina S. Moisés

Unifesp/EPM, Disciplina de Endocrinologia,

Rua Botucatu, 740 - 20. andar,

04034-970 São Paulo SP, Brazil,

E-mail: rmoises@unifesp.br 